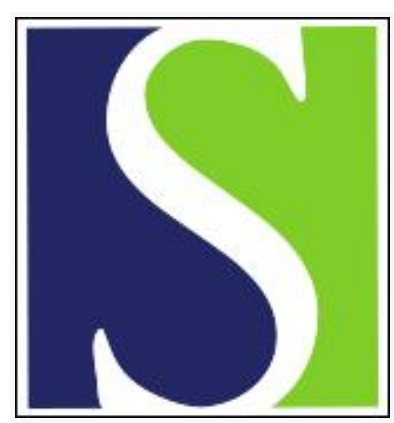

Scand J Work Environ Health 1986;12(4):307-312

https://doi.org/10.5271/sjweh.2148

Issue date: Aug 1986

Vibration syndrome among Finnish forest workers, a follow-up from 1972 to 1983.

by Pyykko I, Korhonen O, Farkkila M, Starck J, Aatola S, Jantti V

This article in PubMed: www.ncbi.nlm.nih.gov/pubmed/3490688

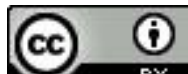




\title{
Vibration syndrome among Finnish forest workers, a follow-up from 1972 to 1983
}

\author{
by Ilmari Pyykkö, MD, ${ }^{1}$ Olli Korhonen, MD, ${ }^{1}$ Markus Färkkilä, MD, ${ }^{2}$ \\ Jukka Starck, PhD, ${ }^{1}$ Seppo Aatola, MSc, ${ }^{3}$ Ville Jäntti, MD, ${ }^{2,4}$
}

\begin{abstract}
PYYKKÖ I, KORHONEN O, FÄRKKILÄ M, STARCK J, AATOLA S, JÄNTTI V. Vibration syndrome among Finnish forest workers, a follow-up from 1972 to 1983. Scand J Work Environ Health 12 (1986) 307-312. A longitudinal survey on the prevalence of vibration syndrome among professional forest workers was conducted from 1972 (118 workers) to 1983 (206 workers). The prevalence of vibration-induced white finger (VWF) was $40 \%$ among the workers in 1972; it gradually declined to $5 \%$ in 1983 . Three new workers developed VWF symptoms during the follow-up period. They had only used saws equipped with antivibration handles. The prevalence of VWF has decreased mainly due to the reduction of chain-saw vibration. The prevalence of paresthesias of the hands and arms declined from $78 \%$ in 1972 to $37 \%$ in 1976, and then increased to $51 \%$ in 1983. The recent increase was thought to be due to static muscle load and the ageing of the workers. No correlation was found between the severity of VWF and peripheral nerve symptoms. No significant changes in muscle fatigue occurred during the follow-up period; it was present in about $10-15 \%$ of the workers. The forest workers subjectively assessed musculoskeletal load and strain as being more harmful than the symptoms of vibration syndrome. The preventive measures aimed at reducing chain-saw vibration, implemented since 1970, have been beneficial and explain the decreased prevalence of VWF.
\end{abstract}

Key terms: longitudinal survey, muscle fatigue, numbness, vibration-induced white finger.

During the 1950s chain saws were heavy and clumsy to use, and their operation time was limited to $1-2$ $\mathrm{h}$ a day (2). This short and interrupted operation seldom caused vibration-induced hazards in Finland. Chain saws became more practical in the early 1960 s, and trees could also be limbed with a saw. Operation time increased to $4-5 \mathrm{~h}$ a day as a result $(13,15)$. Once a certain latency period had passed since the marketing of these saws began, there was an alarming increase in the number of Scandinavian forest workers with Raynaud's phenomenon. The prevalence of vibrationinduced white finger (VWF) among Finnish forest workers in the late 1960s and early 1970s was 40-60\% $(12,15,21)$. These figures corresponded with the findings of other studies conducted in the same period elsewhere in Scandinavia, as well as with those from Australia and England $(5,10,13,20,24)$.

Since 1969 technical changes in the motors and the introduction of vibration damping devices have reduced the frequency-weighted vibration acceleration on the handles of chain saws from $10-20 \mathrm{~m} / \mathrm{s}^{2}$ to about $2-4 \mathrm{~m} / \mathrm{s}^{2}(17,22,25)$. Both our earlier reports from Finland $(18,19)$ and preliminary reports from England $(25,26)$ indicate that a significant decrease

Institute of Occupational Health, Helsinki, Finland,

2 Department of Neurology, Helsinki University Central Hospital, Helsinki, Finland.

3echnical Research Center of Finland, Espoo, Finland.

4 Department of Clinical Neurophysiology, Tampere University Central Hospital, Tampere, Finland.

Reprint requests to: Dr I Pyykkö, Department of Physiology, Institute of Occupational Health, Topeliuksenkatu 41 a A, SF-00250 Helsinki, Finland. in the prevalence of vibration syndrome was taking place, probably due to the decrease in chain-saw vibration.

A longitudinal survey was undertaken to determine the actual situation and changes in the prevalence of vibration syndrome from 1972 to 1983 among a stable population of Finnish forest workers. Reports from the survey have previously been published about the situation in 1972,1975 , and $1980(15,18,19)$.

\section{Subjects and methods}

The investigation was made in connection with compulsory health examinations performed in northern Finland during the winters of 1972, 1975, 1977, 1978, $1979,1980,1981$, and 1983. All forest workers $(N=118$ to 217) supervised by the National Board of Forestry were examined. As the study focused on professional forest workers, only those who had used a chain saw for at least three consecutive years, for a minimum of $500 \mathrm{~h}$ per year, were included in the study. The age distribution and number of forest workers studied in different years are shown in table 1. In addition to the study of all the forest workers, the symptoms of vibration syndrome were evaluated among a subgroup of workers who participated in the study for the entire follow-up period.

Before the examination the forest workers completed a questionnaire on their state of health, use of medications, and symptoms of vibration syndrome. A medical history was recorded, and a physical examination was carried out, particular attention being paid to 
Table 1. Age distribution of forest workers studied in different years.

\begin{tabular}{|c|c|c|c|c|c|c|c|c|c|}
\hline \multirow{2}{*}{$\begin{array}{l}\text { Age } \\
\text { (years) }\end{array}$} & \multicolumn{9}{|c|}{ Year of examination } \\
\hline & 1972 & 1975 & 1976 & 1977 & 1978 & 1979 & 1980 & 1981 & 1983 \\
\hline $\begin{array}{l}20-29 \\
30-39 \\
40-49 \\
50-59\end{array}$ & $\begin{array}{r}32 \\
48 \\
34 \\
4\end{array}$ & $\begin{array}{r}45 \\
57 \\
76 \\
9\end{array}$ & $\begin{array}{l}31 \\
61 \\
70 \\
19\end{array}$ & $\begin{array}{l}37 \\
59 \\
72 \\
21\end{array}$ & $\begin{array}{l}45 \\
64 \\
73 \\
21\end{array}$ & $\begin{array}{l}49 \\
60 \\
77 \\
24\end{array}$ & $\begin{array}{l}47 \\
65 \\
77 \\
28\end{array}$ & $\begin{array}{l}33 \\
62 \\
67 \\
30\end{array}$ & $\begin{array}{l}31 \\
65 \\
67 \\
43\end{array}$ \\
\hline Total & 118 & 187 & 181 & 189 & 203 & 210 & 217 & 192 & 206 \\
\hline
\end{tabular}

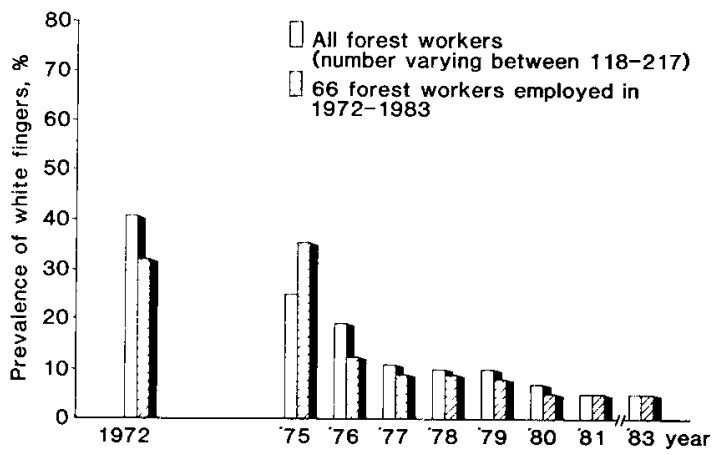

Figure 1. Prevalence of vibration-induced white finger among forest workers in different years.

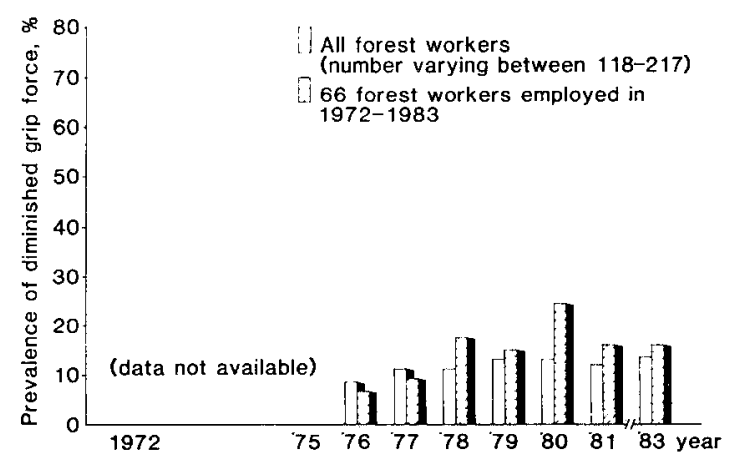

Figure 3. Prevalence of diminished grip force of the upper arms among forest workers in different years.

symptoms and signs of vibration syndrome. The same physician performed all the examinations. The subject was considered to be recovered if more than two years had passed since the last attack of VWF.

The severity of the symptoms of vibration syndrome was determined annually. In addition, for reference, symptoms linked to other major reasons for disability due to forest work were also recorded.

Two groups were formed. Group 1 comprised all the forest workers participating in the study from 1972 to 1983. Group 2 consisted of those 66 forest workers that participated in the study each year.

A cold provocation test was done for all the subjects with a history of white fingers and for a group of forest workers randomly selected each year (16).

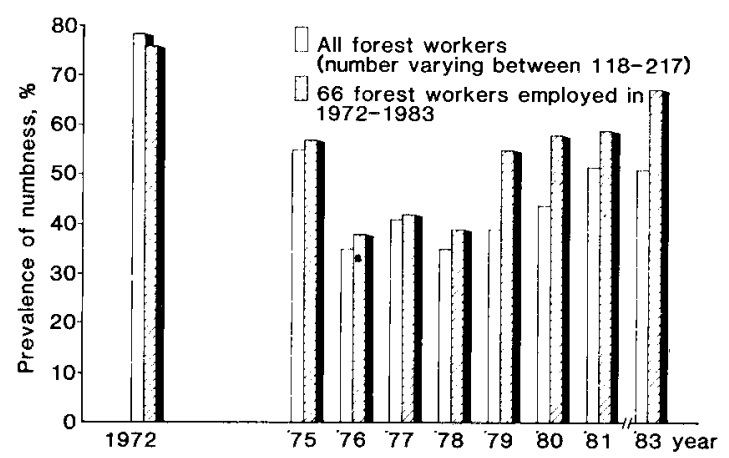

Figure 2. Prevalence of numbness of the hands and arms among forest workers in different years.

The vibration produced by three different generations of chain saws was analyzed according to ISO/DIS 5349 (11). The first-generation chain saw was manufactured in 1958 and had no antivibration isolation. Such saws were still in general use at the end of the 1960 s. The second-generation saw was manufactured in 1972 and represented the first chain saws with antivibration isolation. The third-generation saw was manufactured in 1982 and represented the most upto-date chain saws in professional use.

\section{Results}

\section{Vibration-induced white finger}

In 1972, 52 of 118 forest workers had a history of Raynaud's phenomenon. For five subjects two years had elapsed without an attack of VWF. Thus the prevalence of VWF in 1972 was $40 \%(95 \%$ confidence limits $31-49 \%$ ). During the follow-up period the prevalence of VWF decreased consistently until 1977, after which it has remained about the same (figure 1). The prevalence of VWF among the 206 forest workers examined in 1983 was $5 \%$. Since 1972 only three new subjects have become disabled because of VWF. In one subject with somewhat peculiar VWF, the disorder turned out to be thoracic outlet syndrome. A reduction in the prevalence of VWF similar to that detected for the entire study group was also observed for the 66 forest workers followed for the full duration of the study period. (See figure 1.) 


\section{Numbing of the hands and arms}

Numbing of the hands was a complaint of $78 \%$ of the forest workers in 1972. It occurred more commonly in subjects with VWF than in those without $\left(\chi^{2}=\right.$ $4.27, p<0.05$ ). Numbing of the hands started, on the average, one year later than the first attack of VWF. It had no connection with the severity of VWF, which was evaluated by means of an index value (15).

Numbing of the hands and arms was particularly common at night and was disturbing because it woke the subjects, some of them several times a night. At such times they were forced to rub and shake their hands. During the follow-up period a significant reduction in the prevalence of this symptom was also noticed (figure 2). However, since 1978 the prevalence of symptoms of numbing of the hands has slightly increased to about $51 \%$ ( $44 \%$ in 1980), a result which may be due to an increase in operation time. Paresthesias are more common among forest workers than could be expected among workers not exposed to vibration (23). The prevalence of numbness of the hands has increased more in the 66 workers followed throughout the study than in the total group of forest workers examined annually. (See figure 2 .)

\section{Muscle fatigue}

Muscle fatigue has been analyzed systematically since 1975 , the year we learned that this symptom is a part of the vibration syndrome. That year $36(19.3 \%)$ of all the forest workers had a history of excessive muscle fatigue. During the follow-up study only a slight increase was observed for this symptom, and in 1983 it was still present in $12 \%$ of the forest workers. The extent of muscle fatigue was about the same in both groups of forest workers. Figure 3 shows the changes in such symptoms from 1976 to 1983.

\section{Cold provocation test}

A cold provocation test was done annually for all forest workers with a history of VWF. Figure 4 displays the percentage of positive test results for different years. For both groups of forest workers the curve displays a decreasing tendency that concurs with the decreasing prevalence of VWF.

\section{Weakened occupational performance}

All the forest workers' subjective assessments of disability due to various symptoms in 1976 and 1981 are shown in tables 2 and 3 . We found a significant increase in the prevalence of numbing of the hands and arms which, however, was not reflected as an increase in weakened occupational performance or as a drop in wages. When compared with symptoms caused by strain or overloading of the musculoskeletal system (table 3) symptoms of the vibration syndrome (table 2) caused distinctly less interference with occupational performance. The forest workers rated health prob-

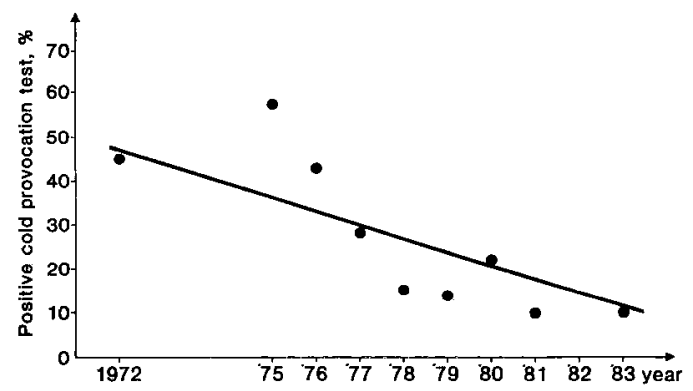

Figure 4. Percentage of positive cold provocation tests among forest workers in different years.

Table 2. Subjective assessment of weakened occupational performance due to symptoms of the vibration syndrome among all the forest workers examined in $1976(\mathrm{~N}=207)$ and 1981 $(N=192)$. The results are expressed as percentages of the total.

\begin{tabular}{|c|c|c|c|c|c|c|}
\hline & \multicolumn{2}{|c|}{$\begin{array}{l}\text { White } \\
\text { fingers }\end{array}$} & \multicolumn{2}{|c|}{$\begin{array}{c}\text { Diminished } \\
\text { muscle } \\
\text { force }\end{array}$} & \multicolumn{2}{|c|}{ Numbness } \\
\hline & 1976 & 1981 & 1976 & 1981 & 1976 & 1981 \\
\hline \multicolumn{7}{|l|}{ Symptom } \\
\hline Not present & 87 & 96 & 89 & 84 & 61 & 45 \\
\hline $\begin{array}{c}\text { Present } \\
\text { Weakened }\end{array}$ & 13 & 4 & 11 & 16 & 39 & $55 * *$ \\
\hline \multicolumn{7}{|l|}{$\begin{array}{l}\text { occupational } \\
\text { performance }\end{array}$} \\
\hline No & 8 & 2 & 4 & 9 & 32 & 48 ** \\
\hline Slight & 3 & 1 & 5 & 5 & 6 & 5 \\
\hline $\begin{array}{c}\text { Considerable } \\
\text { Effect on wages }\end{array}$ & 2 & 1 & 2 & 2 & 1 & 2 \\
\hline $\begin{array}{l}\text { Not essential } \\
\text { Essential }\end{array}$ & $\begin{array}{r}11 \\
2\end{array}$ & $\begin{array}{l}4 * \\
0\end{array}$ & $\begin{array}{l}8 \\
3\end{array}$ & $\begin{array}{r}14 \\
2\end{array}$ & $\begin{array}{r}38 \\
1\end{array}$ & $\frac{52 * *}{3}$ \\
\hline
\end{tabular}

${ }^{*} p<0.05,{ }^{*}{ }^{*} p<0.01, \chi^{2}$ test, difference between 1976 and 1981.

Table 3. Subjective assessment of load and overstrain of the musculoskeletal system for the same forest workers as in table 2. The results are expressed as percentages of the total.

\begin{tabular}{|c|c|c|c|c|c|c|}
\hline & \multicolumn{2}{|c|}{$\begin{array}{l}\text { Pain in the } \\
\text { upper arms }\end{array}$} & \multicolumn{2}{|c|}{ Neck pain } & \multicolumn{2}{|c|}{ Back pain } \\
\hline & 1976 & 1981 & 1976 & 1981 & 1976 & 1981 \\
\hline \multicolumn{7}{|l|}{ Symptom } \\
\hline $\begin{array}{l}\text { Not present } \\
\text { Present } \\
\text { Weakened }\end{array}$ & $\begin{array}{l}74 \\
26\end{array}$ & $\begin{array}{l}69 \\
31 .\end{array}$ & $\begin{array}{l}64 \\
36\end{array}$ & $\begin{array}{l}67 \\
33\end{array}$ & $\begin{array}{l}56 \\
44\end{array}$ & $\begin{array}{l}57 \\
43\end{array}$ \\
\hline $\begin{array}{l}\text { occupational } \\
\text { performance }\end{array}$ & & & & & & \\
\hline No & 14 & 16 & 24 & 20 & 17 & 22 \\
\hline Slight & 10 & 9 & 10 & 9 & 14 & 10 \\
\hline $\begin{array}{c}\text { Considerable } \\
\text { Effect on wages }\end{array}$ & 2 & 6 & 2 & 4 & 13 & 11 \\
\hline $\begin{array}{l}\text { Not essential } \\
\text { Essential }\end{array}$ & $\begin{array}{r}21 \\
5\end{array}$ & $\begin{array}{r}24 \\
7\end{array}$ & $\begin{array}{r}33 \\
3\end{array}$ & $\begin{array}{r}30 \\
3\end{array}$ & $\begin{array}{l}34 \\
10\end{array}$ & $\begin{array}{l}30 \\
13\end{array}$ \\
\hline
\end{tabular}

lems of the back as severe. The overall subjective assessments were similar among the subgroup of workers examined in both 1976 and 1981 (tables 4 and 5).

\section{Vibration of the chain saws}

The most vibration was measured in the chain saw manufactued in 1958 (figure 5). Evaluated according 
to the guidelines in ISO/DIS 5349 (11), the weighted acceleration was $14 \mathrm{~m} / \mathrm{s}^{2}$ for the most harmful frequency component of $125 \mathrm{~Hz}(11)$. The weighted acceleration was much lower in the saw manufactured in 1972 $\left(1.8 \mathrm{~m} / \mathrm{s}^{2}\right)$. The saw manufactured in 1982 had a

Table 4. Subjective assessment of weakened occupational performance due to various symptoms of vibration syndrome among the 145 forest workers examined in both 1976 and 1981. The results are expressed as percentages of the total.

\begin{tabular}{|c|c|c|c|c|c|c|}
\hline & \multicolumn{2}{|c|}{$\begin{array}{l}\text { White } \\
\text { fingers }\end{array}$} & \multicolumn{2}{|c|}{$\begin{array}{l}\text { Diminished } \\
\text { muscle } \\
\text { force }\end{array}$} & \multicolumn{2}{|c|}{ Numbness } \\
\hline & 1976 & 1981 & 1976 & 1981 & 1976 & 1981 \\
\hline Symptom & & & & & & \\
\hline $\begin{array}{l}\text { Not present } \\
\text { Present } \\
\text { Weakened } \\
\text { occupational } \\
\text { performance }\end{array}$ & $\begin{array}{r}91 \\
9\end{array}$ & $\begin{array}{r}95 \\
5\end{array}$ & $\begin{array}{r}93 \\
7\end{array}$ & $\begin{array}{l}86 \\
14\end{array}$ & $\begin{array}{l}65 \\
35\end{array}$ & $\begin{array}{l}45 \\
55 \text { * * }\end{array}$ \\
\hline No & 6 & 3 & 3 & 9 & 30 & $48^{* *}$ \\
\hline Slight & 2 & 1 & 3 & 3 & 4 & 5 \\
\hline $\begin{array}{c}\text { Considerable } \\
\text { Effect on wages }\end{array}$ & 1 & 1 & 1 & 2 & 1 & 2 \\
\hline $\begin{array}{l}\text { Not essential } \\
\text { Essential }\end{array}$ & $\begin{array}{l}8 \\
1\end{array}$ & $\begin{array}{l}5 \\
0\end{array}$ & $\begin{array}{l}6 \\
1\end{array}$ & $\begin{array}{r}12 \\
2\end{array}$ & $\begin{array}{r}35 \\
0\end{array}$ & $\frac{52 * *}{3}$ \\
\hline
\end{tabular}

${ }^{\star} p<0.05,{ }^{* *} p<0.01, \chi^{2}$ test, difference between 1976 and 1981.

Table 5. Subjective assessment of load and overstrain of the musculoskeletal system for the same forest workers as in table 4. The results are expressed as percentages of the total.

\begin{tabular}{|c|c|c|c|c|c|c|}
\hline & \multicolumn{2}{|c|}{$\begin{array}{l}\text { Pain in the } \\
\text { upper arms }\end{array}$} & \multicolumn{2}{|c|}{ Neck pain } & \multicolumn{2}{|c|}{ Back pain } \\
\hline & 1976 & 1981 & 1976 & 1981 & 1976 & 1981 \\
\hline \multicolumn{7}{|l|}{ Symptom } \\
\hline $\begin{array}{l}\text { Not present } \\
\text { Present } \\
\text { Weakened } \\
\text { occupational } \\
\text { performance }\end{array}$ & $\begin{array}{l}78 \\
22\end{array}$ & $\begin{array}{l}70 \\
30\end{array}$ & $\begin{array}{l}63 \\
37\end{array}$ & $\begin{array}{l}64 \\
36\end{array}$ & $\begin{array}{l}59 \\
41\end{array}$ & $\begin{array}{l}57 \\
43\end{array}$ \\
\hline No & $\begin{array}{r}12 \\
9 \\
1\end{array}$ & $\begin{array}{r}14 \\
9 \\
7\end{array}$ & $\begin{array}{r}27 \\
8 \\
2\end{array}$ & $\begin{array}{r}21 \\
10 \\
5\end{array}$ & $\begin{array}{l}15 \\
15 \\
11\end{array}$ & $\begin{array}{l}20 \\
11 \\
12\end{array}$ \\
\hline $\begin{array}{c}\text { Considerable } \\
\text { Effect on wages }\end{array}$ & 1 & 7 & 2 & 5 & 11 & \\
\hline $\begin{array}{l}\text { Not essential } \\
\text { Essential }\end{array}$ & $\begin{array}{r}20 \\
2\end{array}$ & 22 & $\begin{array}{r}35 \\
2\end{array}$ & $\begin{array}{r}32 \\
4\end{array}$ & $\begin{array}{r}35 \\
6\end{array}$ & $\begin{array}{l}29 \\
14\end{array}$ \\
\hline
\end{tabular}

* $p<0.05, \chi^{2}$ test, difference between 1976 and 1981 weighted acceleration of $2.4 \mathrm{~m} / \mathrm{s}^{2}$. The difference in weighted acceleration between the two latest saws was only $2 \mathrm{~dB}$; evaluated with unweighted vibration, the difference was $6 \mathrm{~m} / \mathrm{s}^{2}$.

\section{Discussion}

The forest industry is extremely important to the economy of Finland. In 1966 there were 135000 professional forest workers in this country (9). Technological advances and improved organization have reduced their number. At present (1985) there are only 25000 economically active forest workers, but it is estimated that in 1990 there will still be about 20000 (9).

Since the early 1970 s the number of vibrationinduced health hazards has been decreasing because of a decrease in the prevalence of vibration syndrome and because fewer men are working in forestry. In official records the decrease in the prevalence of vibration syndrome has become visible also in the number of verified cases of occupational diseases (figure 6). There are several reasons for the low number. Undoubtedly some are linked to the national economy, whereas others are due to the poor validity of the objective tests used to detect vibration syndrome and to the minor degree of disability caused by vibration syndrome.

An additional study was made in 1975 in order to verify that the changes in prevalence observed in the rather limited group of forest workers in Suomussalmi was representative of the changes for all of Finland (19). A total of 501 forest workers living in different parts of the country were examined. According to the self-administered questionnaires, VWF was present in $40 \%$ of the 501 forest workers in 1975. The majority of responses from the subjects with VWF indicated that a highly significant decrease had occurred in their subjectively assessed symptoms of this disease over the last few years. Thus the decreased prevalence of VWF observed in the present survey is representative of the changes among forest workers throughout Finland.

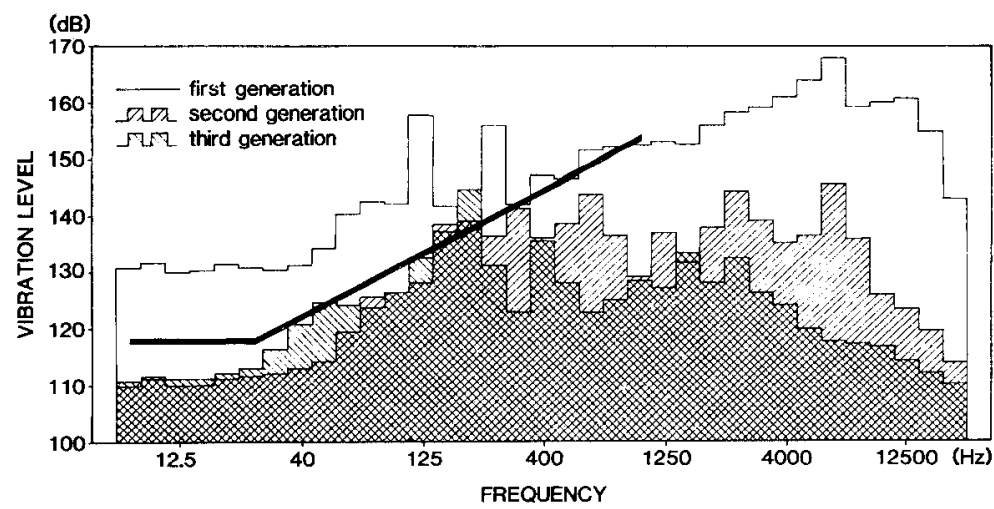

Figure 5. Vibration acceleration of chain saws in 1958, 1972, and 1980 (dB re $10^{-6} \mathrm{~m} / \mathrm{s}^{2}$ ). 
There is still some controversy as to whether or not vibration syndrome is reversible. Agate (1) reported that, in some workers, VWF was first seen some months after they had left a job with vibrating tools. In workers already having VWF, vascular disturbances showed a tendency to progress rather than to disappear after the cessation of work. Other evidence, however, favors the view that VWF is reversible. Steward \& Goda (23) reported that, five years after the cessation of vibration-exposure, $30 \%$ of the subjects no longer experienced attacks of VWF. A follow-up of forest workers operating chain saws in Sweden showed that the prevalence of VWF had decreased from $60 \%$ in 1970 to $5-10 \%$ in 1983 (Gemne, personal communication). In England, a similar study indicated that, in recent years, VWF has become significantly less severe among forest workers, but not to the same extent as in Scandinavia $(25,26)$. A prolonged period of time is required before the pathological reactivity of the vessel subsides $(14,16)$, and the structural changes of the vessel walls regress $(3,8,27)$. In the forest workers of the present study, this recovery period has been very similar to the length of the latency period.

One factor which has had a favorable effect on the course of VWF is the increased use of heated transportation between home and the worksite in the forest, and also during leisure-time trips. If the men who formerly experienced attacks of VWF while riding to and from work on motorcycles would resume riding motorcycles, they would probably start experiencing attacks of VWF again. This claim is supported by the finding of a positive cold provocation test for men who had not had a single attack of VWF for several years (16). Thus some of these men are not really "recovered." Instead they have merely stopped "experiencing attacks," and it is probable that under other conditions they would still suffer from VWF.

The prevalence of extensive muscle fatigue in the hands and arms of forest workers, which ranged from 7 to $19 \%$ of the subjects, indicated that occupational exposure to vibration can cause inadequate muscle contraction (18). Bannister \& Smith (4) showed that the use of vibrating tools is associated with a significant decrease in manipulative dexterity, and so it seems possible that muscular weakness is at least partly due to a disturbance of the fine control of the muscles of the hands. Furthermore, Färkkilä (6) and Färkkilä et al (7) objectively demonstrated that exposure to vibration causes a significant decrease in muscle force in the hands and that the decrease is more advanced in subjects with a history of muscle weakness.

Very often, however, the same subjects who displayed extensive symptoms of peripheral neuropathy also had significantly decreased muscle force in the test. When both muscle force and nerve conduction velocity were measured in a separate study, a correlation was found between decreased muscle force and slowed nerve conduction velocities (Pyykkö et al, unpublished

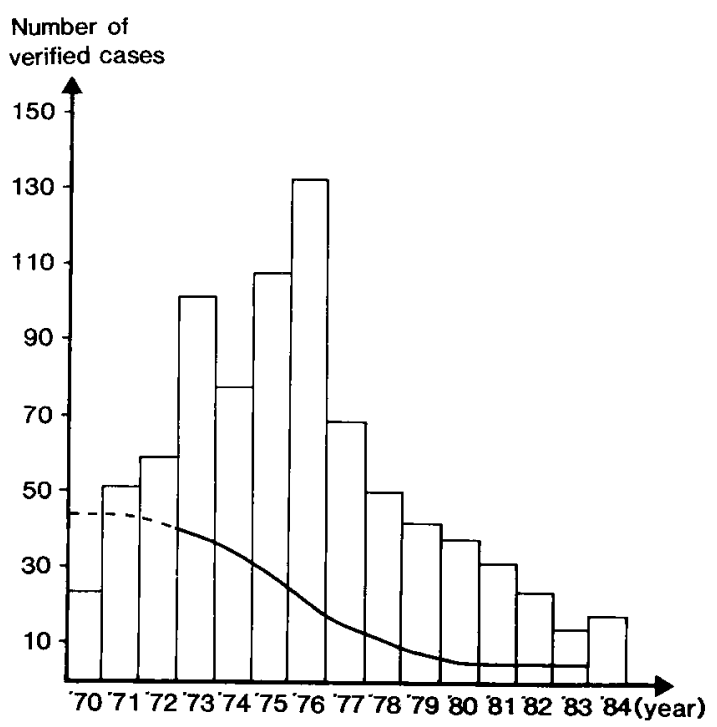

Figure 6. Number of cases of vibration syndrome newly verified as an occupational disease in different years (bars). [The prevalence $(\%)$ of vibration-induced white finger is shown by a broken (prevalences determined retrospectively) and unbroken (prevalences determined during the survey) line.]

observation). Hence it seems likely that degeneration in the nerves innervating the muscles is the immediate cause for the complaint of excessive muscle fatigue.

Both the prevalence of muscle fatigue and the high prevalence of numbing of the hands and arms decreased slightly among the forest workers studied. An external factor affecting the development of muscle fatigue was the slight decrease in workhours. The annual chain-saw operating time was reduced from 1300 $\mathrm{h}$ in the early $1970 \mathrm{~s}$ to $1100 \mathrm{~h}$ in the late 1970s, and increased again to $1300 \mathrm{~h}$ in the early 1980s. Furthermore, it is possible that ageing prevents the detection of full recovery from the symptoms themselves.

\section{Conclusion}

The spread in the use of chain saws that occurred in the 1960 s caused a gradual increase in the prevalence of VWF among forest workers in Finland. The latency period for VWF was about five years. In Finland the highest morbidity was reached in 1970. In 1972, $40 \%$ of the forest workers in one forestry district had VWF, but in the follow-up study in 1980 the prevalence had decreased to $5 \%$. A similar peak and a similar decrease in prevalence were also observed for numbness of the hands and arms.

\section{References}

1. Agate JN. An outbreak of cases of Raynaud's phenomenon of occupational origin. Br J Ind Med 6 (1949) 144-163.

2. Aho $K$. Method of measuring the vibration of chain saws and evaluating the results. Valtion painatuskeskus, Hel- 
sinki 1971, pp 1-13. (Vakola study report no 8).

3. Ashe WF, Cook WT, Old JW. Raynaud's phenomenon of occupational origin. Arch Environ Health 5 (1962) 333-343.

4. Bannister PA, Smith FM. Vibration induced white fingers and manipulative dexterity. Br J Med 29 (1972) 265-267.

5. Barnes R, Longley EO, Smith ARB, Allen JG. Vibration disease. Med J Aust 1 (1969) 901-905.

6. Färkkilä M. Grip force in vibration disease. Scand J Work Environ Health 4 (1978) 159-166.

7. Färkkilä M, Pyykkö I, Korhonen O, Starck J. Vibrationinduced decrease in the muscle force in lumberjacks. Eur J Appl Physiol 43 (1980) $1-9$.

8. Gurdjian ES, Walker LW. Traumatic vasospastic disease of the hand (white fingers). J Am Med Assoc 129 (1945) $668-672$.

9. Heikinheimo L, Heikinheimo M, Lehtinen L, Reunala A. Suomalainen metsätyömies. Werner Söderström Oy, Porvoo 1972.

10. Hellstrem $\mathbf{B}$, Lange Andersen $\mathbf{K}$. Vibration injuries in Norwegian forest workers. $\mathrm{Br} \mathbf{J}$ Ind Med 29 (1972) $255-263$.

11. International Organization for Standardization. Guide for the measurement and the assessment of human exposure to vibration transmitted to the hand. Geneva 1983, (ISO/DIS 5349).

12. Kumlin T, Wiikeri D, Sumari P. Radiological changes in carpal and metacarpal bones and phalanges caused by chain saw vibration. Br J Ind Med 30 (1973) 71-73.

13. Kylin B, Lindström I-M. Hälso- och miljöundersökning bland skogsarbetare. AI-rapport 5 (1968) 44-62.

14. Olsen N. A longitudinal study of the vasoconstrictor response to cold in Danish forestry workers. In: Institute of Occupational Health. Abstract of the Fourth International Symposium on Hand-Arm Vibration. Helsinki 6-8 May, 1985. Helsinki 1985, p 11.

15. Pyykkö I. The prevalence and symptoms of traumatic vasospastic disease among lumberjacks in Finland. Work Environ Health 11 (1974) 118-131.

16. Pyykkö I, Färkkilä M, Korhonen $O$, Starck J, Jäntti V. Cold provocation tests in the evaluation of vibrationinduced white finger. Scand $\mathrm{J}$ Work Environ Health 12 (1986) 254-258.
17. Pyykkö I, Färkkilä M, Hoikkala M, Korhonen $O$, Nurminen $M$, Starck J. Hand-arm vibration in the etiology of hearing loss in lumberjacks. Br J Ind Med (1982) $281-289$.

18. Pyykkö I, Korhonen OS, Färkkilä MA, Starck JP, Aatola SA. A longitudinal study of the vibation syndrome in Finnish forestry workers. In: Brammer AJ, Taylor W, ed. Vibration effects of the hand and arm in industry. John Wiley \& Sons, New York, NY 1982, pp 157-167.

19. Pyykkö I, Sairanen E, Korhonen O, Färkkilä M, Hyvärinen $\mathrm{J}$. A decrease in the prevalence and severity of vibration-induced white fingers among lumberjacks in Finland. Scand J Work Environ Health 4 (1978) $246-254$.

20. Riddle HFV, Taylor W. Vibration-induced white finger among chain sawyers nine years after the introduction of anti-vibration measures. In: Brammer AJ, Taylor W, ed. Vibration effects on the hand and arm in industry. John Wiley \& Sons, New York, NY 1982, pp 168-172.

21. Seppäläinen A-M. Peripheral neuropathy in forest workers: A field study. Work Environ Health 9 (1972) $106-111$.

22. Starck J. High impulse acceleration levels in hand-held vibratory tools: An additional factor in the hazards associated with the hand-arm vibration syndrome. Scand J Work Environ Health 10 (1984) 171-178.

23. Steward AM, Goda DF. Vibration syndrome. Br J Ind Med 27 (1970) 19-27.

24. Taylor W, Pelmear PL, Hempstock TI, O'Connor DE, Kitchener JR. Correlation of epidemiological data and the measured vibration. In: Taylor W, Pelmear PL, ed. Vibration white finger in industry. Academic Press, London 1975, pp 123-133.

25. Taylor W, Pelmear PL, Hempstock TI, O'Connor DE, Kitchener JR. A longitudinal study of Raynaud's phenomenon in chain saw operators. In: Taylor W, Pelmear $\mathrm{PL}$, ed. Vibration white finger in industry. Academic Press, London 1975, pp 15-20.

26. Taylor W, Pearson RL, Keighley GD. Vibration syndrome in forestry commission chain saw operators. $\mathrm{Br}$ J Ind Med 28 (1971) 83-89.

27. Walton KW. The pathology of Raynaud's phenomenon of occupational origin. In: Taylor W, ed. The vibration syndrome. Academic Press, London 1974, pp 109-119. 